Journal of Molecular Genetics 2 (1): 10-14, 2010

ISSN: $2070-4267$

(C) Medwell Journals, 2010

\title{
Detection of Polymorphisms in the Bovine Leptin (LEP) Gene: Association of a Single Nucleotide Polymorphism With Breeding Value of Milk Traits in Iranian Holstein Cattle
}

\author{
${ }^{1}$ A. Javanmard, ${ }^{1} \mathrm{~K}$. Khaledi, ${ }^{1} \mathrm{~N}$. Asadzadeh and ${ }^{2}$ A.R. Solimanifarjam \\ ${ }^{1}$ Department of Animal Science, Faculty of Agriculture, University Putra Malaysia, \\ 43400 UPM Seldgang, Selangor, Malaysia \\ ${ }^{2}$ Department of Animal Genetics and Breeding, \\ Animal Science Research Institute of Iran (ASRI), Karaj, Iran
}

\begin{abstract}
The objective of this study was to assess the association of polymorphism in leptin gene with breeding value of milk traits in Iranian Holstein cattle. Traits analyzed were breeding values of Milk and Fat production. A strategy employing polymerase chain reaction was used to amplify a $422 \mathrm{bp}$ from blood, semen. Digestion of polymerase chain reaction products with Sau3AI revealed two alleles: Allele A was 390, 32 fragment and allele B was 303, 88 and 32 (only 303 fragment visible on the gel). Three patterns were observed frequencies were $0.900,0.100$ and 0.00 for $\mathrm{AA}, \mathrm{AB}$ and $\mathrm{BB}$, respectively $(\mathrm{p} \leq 0.21)$. The $\mathrm{AB}$ bulls were superior for milk fat production, in relation to homozygous AA. The Bovine leptin gene is strong candidates in the dairy cattle QTL search. This polymorphism could be further evaluated for marker assisted selection and the developed PCR methodology would expedite screening for large numbers of animal required for such studies.
\end{abstract}

Key words: Milk traits, leptin, holstein cattle, polymorphism, screening methodology, Iran

\section{INTRODUCTION}

Traditionally, dairy cattle breeders have made genetic progress by using phenotypic information on animal available for selection and their relative. More recently, advanced statistical methodology such as Best Linear Unbiased Prediction (BLUP) has been adapted to better separate environmental from genetic effects (Georges, 1998). These methods all treat the true, unknown genotype of an individual as black box and rely on average population correlations between phenotypes and genotypes to predict the genetic merit of selection candidates. However, molecular genetic techniques are currently available that allow direct genotyping for candidate genes using PCR (Davis and DeNise, 1998). In corporation of molecular data is advantageous when the habitability is low particularly if a large part of the additive Genetic variance can be described to the QTLs being considered (Smith and Simpson, 1986).

Candidate genes are chose for study on the basis of knows relationship between biochemical and physiological processes. Leptin (Greek, Leptos thin or small) is a $16 \mathrm{KD}$ a protein that is synthesized by adipose tissue and is involved in regulation of feed intake, energy balance and fertility and immune functions (Hossner,
1998). Leptin treatment of animals has been shown to cause a decrease in food intake, body weight loss, fat depth weight loss and increase in energy metabolism. Therefore, leptin not only causes reduced food intake but the potential body weight losses are enhanced due to an increased metabolic rate leptin may be involved in regulating reproduction in that if may also act as the signal to the reproductive system that sufficient body fat exists to support a successful conception and pregnancy (Ltenson and Castracane, 2000). In cattle, the leptin gene is located on chromosome 4. It consists out of three exons and two introns of which only 2 exons are translated into protein. The coding region of the leptin gene (501 nucleotide in length) is contained in second exon and 3 which are separated by introns of approximately $2 \mathrm{~kb}$. The leptin gene promoter region spans is approximately $3 \mathrm{~kb}$. Lindersson reported QTL for milk production traits close to the leptin gene $(82.8 \mathrm{cM})$. They found QTL for milk, fat and protein yield at 65 and $85 \mathrm{cM}$ and for fat and protein percentage at 75 and $95 \mathrm{cM}$ of this gene, respectively. The leptin gene itself is considered a potential QTL, influencing different production traits in cattle. Leptin binds to a receptor mainly localized on neuropeptid-Yneurons. NPY in hypothalamus also appear to play a key role in the integration of feeding behavior with internal signals of body energy status (Kuenzel and Fraley, 1995).

Corresponding Author: A. Javanmard, Department of Animal Science, Faculty of Agriculture, University Putra Malaysia, 43400 UPM Seldgang, Selangor, Malaysia 
Indeed, decrease leptin concentration during conditions of food deprecation lead to impaired immune capabilities, more specifically leptin links the pro-inflammatory $\mathrm{T}$ helper immune response. Wilkins and Davey (1997) reported restriction fragment length polymorphisms of the bovine leptin gene. Fitzsimmons (1999) demonstrated that the BM1500 microsatellite located near the gene produced alleles whose frequencies were associated with different levels of fatness in four breeds of beef cattle. Liefers et al. (2002) reported that heifers with the Sau3IA-AB genotype produce $1.32 \mathrm{~kg}$ day ${ }^{-1}$ more milk and consume $0.73 \mathrm{~kg}^{-2}$ more food compared with the SauBAI-AA genotype.

They suggested that RFLP-B alleles could yield a higher milk production without negatively affecting energy balance and fertility. Buchanan et al. (2003) reported $\mathrm{T}$ allele of bovine leptin gene produced more milk (1.5 $\left.\mathrm{kg} \mathrm{day}^{-1}\right) \mathrm{Vs}$ CC animals) and higher somatic cell count linear scores without significantly affecting milk fat or protein percent over the entire lactation and they suggested that the milk yield advantage, observed in cows homozygous you for $\mathrm{T}$ allele could represent a major economic advantage to dairy producers.

These results indicated that the leptin TT genotype is associated with increased milk and protein yield, without changing yield of milk fat. Lagonigro et al. (2003) reported association of five SNP bovine leptin gene with feed Intake and fat-related traits was evaluated. Individuals with genotype. A/T an exon 2 had 19\% greater mean feed intake than individuals with genotype AA. Almeida et al. (2003) reported the to finding two allele seem to increase calving interval by a bout 79 and 81 days, respectively therefore selection against carriers of these mutation could improve calving interval by at least 2 months despite the seasonality of the mating period employed here. In this study, PCR-RFLP was used to detect the polymorphism in Bovine leptin gene; intron region and the relationship between milk traits of Iranian Holstein were analyzed.

\section{MATERIALS AND METHODS}

Animals and DNA extraction method: Blood, semen samples were randomly collected from 66 Iranian Holstein cattle. They were obtained from Iran animal breeding center animal breeding stations. Authorized veterinarian collected Blood samples for DNA genotyping from tail vein. Blood was collected on $\mathrm{K}_{2}$ EDTA and stored at $-20^{\circ} \mathrm{C}$ for few weeks or $-70^{\circ} \mathrm{C}$ up to several months. DNA was extracted from blood or semen following previously reported procedures. DNA concentration were calculated by spectrophotometry by taking the optical density at a wave length of $260 \mathrm{~nm}$.
PCR-RFLP: Amplified region is located in the intron between two exons of leptin. The genomic bovine leptin sequence which consists of three exons was obtained from Gene Bank (Accession Number U50365) (Pomp et al., 1997). The PCR reaction as described by Liefers et al. (2002). The sequence of the forward and reverse primers, respectively were:

\section{Forward primer:}

\section{5'-TGGAGTGGCTTGTTATTTTCTTCT-3'}

\section{Reverse primer:}

\section{3'-GTCCCCGCTTCTGGCTACCTAACT-3'}

PCR condition were $2.25 \mathrm{mM} \mathrm{MgCl}_{2}, 200 \mu \mathrm{m}$ dNTP, $1 \mu \mathrm{m}$ of each primer, 50-100 ng of genomic DNA and 0.2 Taq DNA polymerase the first cycles of the was $3 \mathrm{~min}$ at $94^{\circ} \mathrm{C}, 1 \mathrm{~min}$ at $55^{\circ} \mathrm{C}$ and $1 \mathrm{~min}$ at $72^{\circ} \mathrm{C}$ followed by 34 cycle of $45 \mathrm{sec}$ at $94^{\circ} \mathrm{C} 1 \mathrm{~min}$ at $55^{\circ} \mathrm{C}, 1 \mathrm{~min}$ at $72^{\circ} \mathrm{C}$ and ending with a $10 \mathrm{~min}$ extension phase at $72^{\circ} \mathrm{C} \mathrm{PCR}$ product for each sample was digested with 10 unit of Sau3AI at $37^{\circ} \mathrm{C}$ for overnight gels were stained with $0.5 \mathrm{mg} \mathrm{L}^{-1}$ ethidium bromide for $20 \mathrm{~min}$. Destained and photographed.

Statistical analysis: For estimation of genotype and allele frequencies it used (Yeh et al., 1999) POPgene software (Version 1.31) and for association between Breeding Value (BV) recodes and genetic information we used SAS package. About 3007 samples were made representing bulls progeny tested during 1991-2004. Differences in allele frequencies of the Sau3AI of Holstein bulls were tested by chi-square test. The Estimated Breeding Values (EBVs) of the bulls for milk, fat, yields were obtained from the February 2004 Iranian National Dairy Evaluations which were based on the Best Linear Unbiased Procedure (BLUP) with an animal model. Regression analyses were performed in which EBV for milk, fat, protein yield and fat and protein percent were the dependent variables and the genotype was the independent variable. The model included fixed effects of herd-year- season and age group of sires. The effect of Leptin genotypes on the EBVs for milk, fat yields were then analyzed using least squares methods. The estimated breeding values from the national evaluation system represent the best available estimates of the additive genotype of the bulls. The effect of birth year of the bulls was included in the model to account for genetic trend. The model used was as follows: 


$$
\mathrm{Y}_{\mathrm{ijk}}=\mu+(\text { Year })_{\mathrm{i}}+(\mathrm{Sau} 3 \mathrm{AI}) \mathrm{j}+\mathrm{e}_{\mathrm{ij} \mathrm{k}}
$$

Where:

$Y_{\mathrm{ijkl}}=$ The breeding value (milk, fat yields) of the bull is the least squares estimate of the mean of the trait

Year $_{\mathrm{i}}=$ The effect of the ith birth year of the bull (genetic trend)

Sau3AI $\mathrm{A}_{\mathrm{j}}=$ The effect of the $\mathrm{j}$ Sau3AI genotype $(\mathrm{j}=1,2$, 3 ), type 3 sum of squares were used to evaluate the effect of Leptin polymorphisms. Differences in the estimated breeding values were compared by least squares procedures

\section{RESULTS AND DISCUSSION}

DNA extration showed high quality of DNA Fig. 1 PCR-RFLP in the intron between two exons of the bovine leptin gene was detected. There were two Sau3AI sites in 422 bp fragments. The digested AA PCR product exhibited two fragments of 390 and $32 \mathrm{bp}$ (not detected on the gel). For the BB genotype exhibited 303, 88 and $32 \mathrm{bp}$ (only $303 \mathrm{bp}$ fragments were visible). Figure 2 and 3

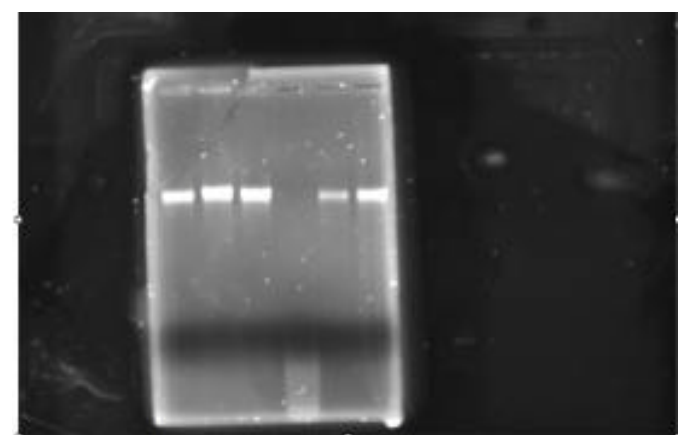

Fig. 1: Quality of extracted DNA by Quiagen Kit

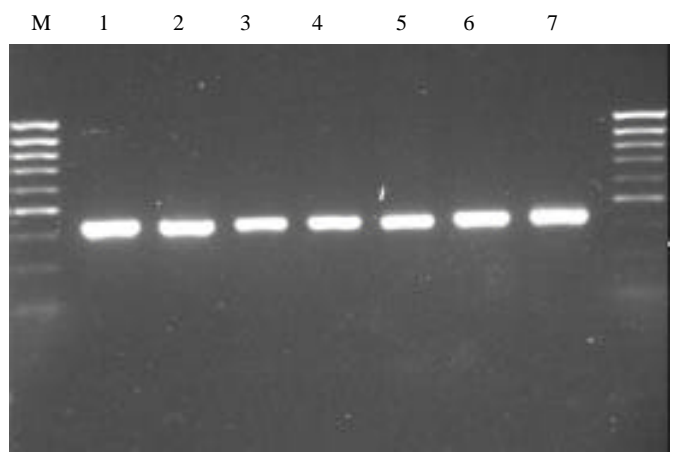

Fig. 2: PCR product size of samples for bovine leptin gene ( $422 \mathrm{bp}$ from second interon of bovine leptin gene) shows PCR product size and Fig. 4 shown the restriction patterns of the three genotypes $\mathrm{AA}, \mathrm{AB}$ and $\mathrm{BB}$. They confirmed mutation GAC GAT (c-to-t) transversion the number of individual with different genotypes and allele frequencies for this polymorphism of leptin gene in Holstein cattle are shown in Table 1.

The frequency of the A allele was 0.90 and 0.10 and that of $\mathrm{B}$ allele was 0.00 , respectively. Figure 5 shows that the genotype and the allele frequencies of Sau3AI polymorphisms in the intron region of bovine leptin gene in Iranian Holstein cattle. Least squares means and standard division were shown in Table 2 for effects of bovine leptin on milk production. The polymorphism at the bovine leptin gene was associated with milk fat $(\mathrm{p} \leq 0.005)$ But animal with AA had lower milk fat than genotype $\mathrm{AB}$. No association was detected between bovine leptin gene and milk production $(\mathrm{p} \leq 0.005)$.

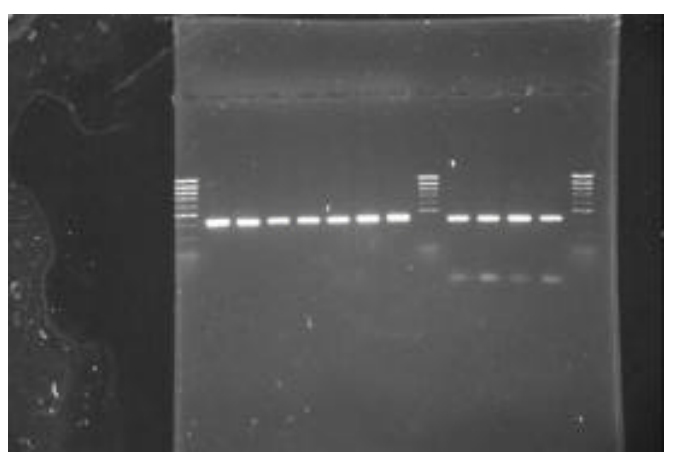

Fig. 3: PCR product size of samples for bovine leptin gene ( $422 \mathrm{bp}$ from second interon of bovine leptin gene)

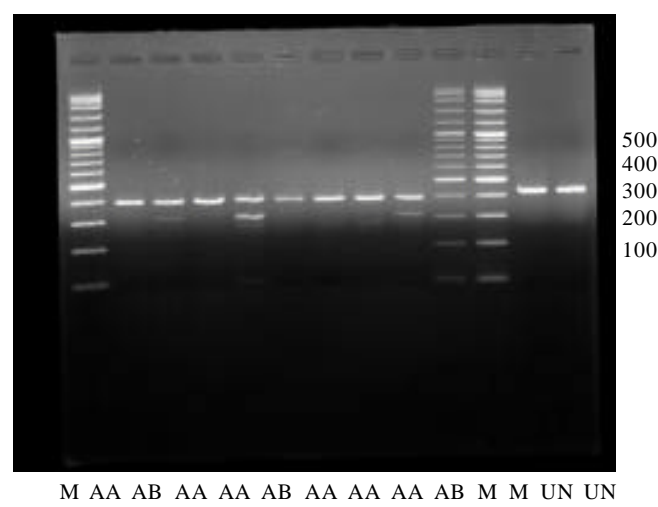

Fig. 4: Genotypes for Bovine leptin gene on a $2 \%$ agarose gel. Lane 1,10 and 11 are promaga $100 \mathrm{bp}$ marker, Lane 12,13 are Uncut PCR product. Lane 2,4, 6, 7 and are AA genotypes and lanes 3,5 and 9 are $\mathrm{AB}$ 
Table 1: The genotypes and allele frequencies of Sau3AI polymorphisms in the intron region of bovine leptin gene in Iranian Holstein cattle

\begin{tabular}{lc}
\hline Factors & Frequency \\
\hline Genotype & \\
AA & 0.90 \\
AB & 0.10 \\
BB & 0.00 \\
Allele & \\
A & 0.95 \\
B & 0.05 \\
\hline
\end{tabular}
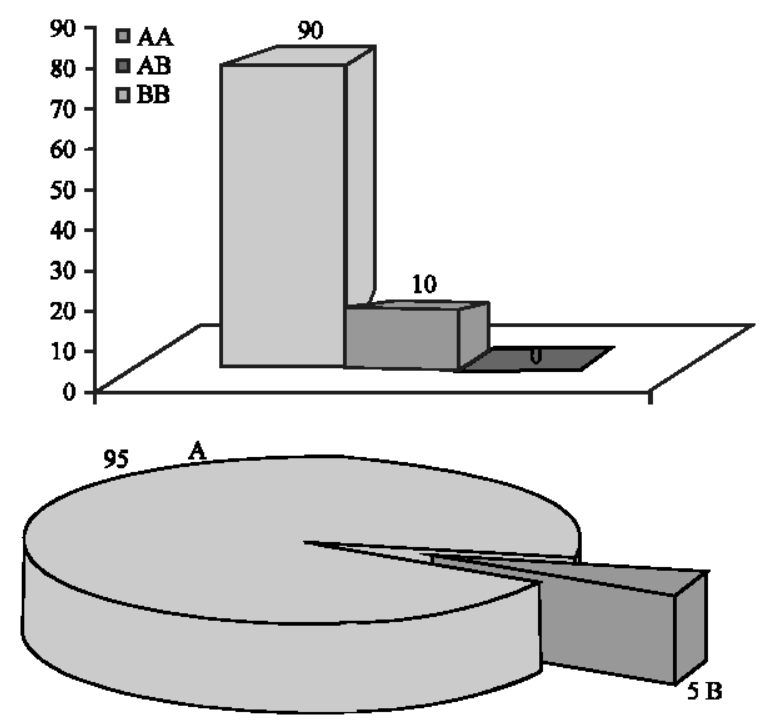

Fig. 5: The genotypes and allele frequencies of Sau3AI polymorphisms in the intron region of bovine leptin gene in Iranian Holstein cattle

An increasing number of scientific study have reported specific roles of leptin in the control of milk, energy balance, meat quality, immune system and reproductive functions.

It is now generally accepted that leptin maybe a strong candidate gene for economically important, production traits such as back fat thickness, feed intake and reproduction function. Recent evidence suggests new key roles for leptin during pregnancy and milk production.

For example, it was reported in humans and rats that the circulating maternal leptin concentration increases during pregnancy and then falls to less than pre pregnancy concentrations around parturition.

Several polymorphisms in this gene have been found. In exon 2, two RFLP were described: ClaI (an A/T substitution resulting in an AA change from tyrosine to phenylalanine) (Lagonigro et al., 2003) and Kpn2I (a C/T substitution resulting in an AA change from argi-nine to cysteine) (Buchanan et al., 2003). Another 2 RFLP were identified in exon 3: NruI (a C/T substitution resulting in a change from valine to alanine) (Lagonigro et al., 2003)
Table 2: Least squares mean, and standard deviation for the effect of bovine leptin on milk production traits in Iranian Holstein cattle

\begin{tabular}{lcll}
\hline Production & Genotypes & LSM \pm SD & Analysis \\
\hline Milk (kg) & AA & $1332 \pm 260.95$ & \\
& AB & $1564.5 \pm 28.79$ & NS \\
\multirow{3}{*}{ Fat $(\mathrm{kg})$} & BB & - & \\
& AA & $4.71 \pm 5.71^{\text {a }}$ & \\
& AB & $43.41 \pm 2.89^{b}$ & $\mathrm{p} \leq 0.21$ \\
\hline
\end{tabular}

and $\mathrm{Hph} \mathrm{I}$ (a $\mathrm{C} / \mathrm{T}$ substitution resulting in a change from alanine to valine) (Haegeman et al., 2000). Moreover, a Sau3AI polymorphism in intron 2 was found (Pomp et al., 1997). In addition, in the BovMap database (http://locus.jouy.inra.fr), 19 other single nucleotide polymorphisms are listed. Liefers et al. (2002) reported that Sau3AI-AB genotype product $1.32 \mathrm{~kg}^{\text {days }}{ }^{-1}$ more milk and consume $0.37 \mathrm{~kg}$ days ${ }^{-1}$ more food compared with the Sau3AI-AA genotype.

Madeja et al. (2004) reported that the HphI polymorphism has a significant effect on milk and protein yield. Animals with the TT genotype had approximately $2 \mathrm{x}$ higher estimated breeding values for milk and protein yields. No effect was found for the other 2 polymorphisms.

The presence of a rare $\mathrm{C}$ allele (Sau3AI) (associated with some cattle breeds, e.g., Pomp et al., 1997) was also related to fat and protein content in the Polish Black and White cattle (Zwierzchowski et al., 2002). Feuermann et al. (2004) reported expression of leptin in tissue culture from mammary glands of lactating cows was enhanced 2.2-fold by prolactin.

\section{CONCLUSION}

These findings indicated that leptin plays an important role in mammary gland lactogenesis and that the expression of leptin requires the presence of prolactin. Other related projected will need to evaluation Relationships between this polymorphism with milk production and reproduction and feed intakes traits.

\section{ACKNOWLEDGEMENT}

Special thanks have to be made to Dr. A. Mohammadi and his cooperation during the conduct of experiment.

\section{REFERENCES}

Almeida, S.E., E.A. Almeida, J.C.F. Moraes and T. Weimer, 2003. Molecular marker in the LEP gene and reproductive performance of beef cattle. J. Anim. Breed. Genet., 120: 106-113. 
Buchanan, F.C., A.G. van Kessel, C. Waldner, D.A. Christensen, B. Laarveld and S.M. Schmutz, 2003. Hot topic: An association between a leptin single nucleotide polymorphism and milk and protein yield. J. Dairy Sci., 86: 3164-3166.

Davis, G.P. and S.K. DeNise, 1998. The impact of genetic markers on selection. J. Anim. Sci., 76: 2331-2339.

Feuermann, Y., S.J. Mabjeesh and A. Shamay, 2004. Leptin affects prolactin action on milk protein and fat synthesis in the bovine mammary gland. J. Dairy Sci., 87: 2941-2946.

Fitzsimmons, C.J., 1999. An investigation into leptins roles a candidate gene for carcass fat level in beef cattle. M.Sc. Thesis, University of Saskatchewan Saskatoon.

Georges, M., 1998. Perspectives for Marker Assisted Selection in Dairy Cattle Breeding: Milk Composition, Production and Biotechnology. CABI, USA.

Haegeman, A., A. van Zeveren and L.J. Peelman, 2000. New mutation in exon 2 of bovine leptin gene. J. Anim. Genet., 31: 79-79.

Hossner, K.L., 1998. Cellular, molecular and physiological aspects of leptin: Potential application in animal production. Can. J. Anim. Sci., 78: 463-472.

Kuenzel, W.J. and G.S. Fraley, 1995. Neuropeptid Y: Its in the neural regulation of reproductive Function and food Intake in mammalian species. Poult. Avian Biol. Rev., 6: 185-209.

Lagonigro, R., P. Wiener, F. Pilla, J.A. Woolliams and J.L. Williams, 2003. A new mutation in the coding region of the bovine leptin gene associated with feed intake. Anim. Genet., 34: 371-374.
Liefers, S.C., R.F. Veerkamp and T. Vander-Lene, 2002. Association between leptin gene polymorphism and production, live weight energy balance, feed intake and fertility in Holstein heifers. J. Dairy Sci., 85: 1633-1638.

Ltenson, M.C. and V.D. Castracane, 2000. Leptin in pregnancy. Biol. Reprod., 63: 1219-1228.

Madeja, Z., T. Adamowicz, A. Chmurzynska, T. Jankowski, J. Melonek, M. Switonski and T. Strabel, 2004. Short communication: Effect of leptin gene polymorphisms on breeding value for milk production traits. J. Dairy Sci., 87: 3925-3927.

Pomp, D., T. Zou, A.C. Clutter and W. Barendse, 1997. Rapid communication mapping of leptin to bovine chromosome 4 by linkage analysis of a PCR-based polymorphism. J. Anim. Sci., 75: 1427-1427.

Smith, C. and P. Simpson, 1986. The use of genetic polymorphisms in livestock improvement. J. Anim. Breed. Genet., 103: 205-217.

Wilkins, R.J. and H.W. Davey, 1997. A polymorphic microsatellite in the bovine leptin gene. Anim. Genet., 28: 376-376.

Yeh, F.C., R. Yang and T. Boyle, 1999. POPGENE Version 1.31: Microsoft Window-based free software for Population Genetic Analysis. University of Alberta, Edmonton, AB, Canada.

Zwierzchowski, L., J. Krzyzewski, N. Strzalkowska, E. Siadkowska and Z. Ryniewicz, 2002. Effects of polymorphism of growth hormone, pit-1 and leptin genes, cow's age, lactation stage and somatic cell count on milk yield and composition of Polish black and white cows. Anim. Sci. Pap. Rep., 20: 213-227. 